\title{
Coping with the Standards Regime: Analyzing Export Competitiveness of Indian Seafood Industry
}

\author{
Jayasekhar Somasekharan ${ }^{1}$, Harilal K. N. ${ }^{2} \&$ Parameswaran M. ${ }^{2}$ \\ ${ }^{1}$ Division of Social Sciences, CPCRI, Kasaragod, Kerala, India \\ ${ }^{2}$ Centre for Development Studies, Thiruvananthapuram, India \\ Correspondence: Jayasekhar Somasekharan, Division of Social Sciences, CPCRI, Kasaragod, Kerala, India. Tel: \\ 91-996-1991-692. E-mail: jaysekhars@yahoo.co.in
}

Received: September 18, 2012 Accepted: October 18, 2012 Online Published: November 2, 2012

doi:10.5539/sar.v2n1p98 URL: http://dx.doi.org/10.5539/sar.v2n1p98

\begin{abstract}
In this research paper a Constant Market Share (CMS) approach was employed to learn export performance dynamics of Indian seafood (shrimps and cephalopods) in the major export destinations (EU, USA and select Asian countries), which accounts for a sizeable market for Indian seafood. The Constant Market Share model was used to disintegrate the growth in exports of seafood into market size effect, market composition effect and competitiveness effect. The analysis was performed for the seafood exports for a span of 12 years from the year 1996 to the year 2007, the period during which India had to face severe challenges from evolving food safety regulations in the EU and USA. The analysis was extended to account for the competitiveness at dis-aggregated commodity level. In the present study we observed enhanced competitiveness in the case of cephalopods while shrimp exports were less competitive. To a certain extent it shows that trade facilitating as well as trade restricting effects can coexist as an impact of strict food safety regulations.
\end{abstract}

Keywords: competitiveness, food safety, seafood industry

\section{Introduction}

Multitude of studies put forth the argument that stricter food safety standards in the developed countries are detrimental to the exports from developing nations in terms of market access and export competitiveness (Anders \& Caswell, 2009; Henson, 2007). An entirely new regime of food safety standards on India's fishery exports were enforced and made mandatory by the European Union from 1997 onwards. This has eventually directed a provisional prohibition on seafood exports from the country and succeeded a catastrophe in the fishery export sector when the necessary regulations were tough to comply within a short span of time. Subsequent to this, in December 1999, USA which is another important destination of seafood from India came up with mandatory HACCP seafood law (Henson \& Jaffee, 2008). Nevertheless, the seafood processing and exporting industry had proactively occupied in restructuring their activities in line with the food safety requirements of the destination markets. Any policy level decisions regarding the market access of fishery products to EU and USA are certain to affect India, because 42 percent of India's total fishery export share goes to these destinations (Table 1). Having experienced some serious setbacks and restructuring of the seafood industry, it is interesting to analyze the impact of such a reshuffling process on the export competitiveness of the sector. The relevance of the present study lies exactly at this context. It is a known fact that several factors in isolation and with synergy decide the trade competitiveness of a nation. Therefore it is crucial to delineate and highlight the key factors which affect the trade competitiveness. More over, such an attempt would certainly hold important stake in policy decisions. In this background, an attempt is made to analyze the impact of India's seafood export performance from 1996 to 2007, which is considered as the regime of food safety regulations and resultant evolution of coping up strategies. Although there could be umpteen factors which determines the export competitiveness of a nation, the relative market share of a country's exports in the international market is the ready reckoner of its competitiveness. The paper employs a Constant Market Share (CMS) approach to study India's export performance of seafood (shrimp and cephalopod) in the markets of the EU, USA and select Asian countries. 
Table 1. Marketwise export of Indian seafood

\begin{tabular}{lll}
\hline Country & Export(million US\$) & Share (\%) \\
\hline Japan & 373.0 & 13.1 \\
USA & 438.5 & 15.3 \\
EU & 765.2 & 26.8 \\
China & 440.1 & 15.4 \\
South East Asia & 469.4 & 16.4 \\
Middle East & 148.2 & 5.2 \\
Others & 222.6 & 7.8 \\
\hline Total & 2856.9 & 100.0 \\
\hline
\end{tabular}

Source: Marine Products Export Development Authority (MPEDA), India.

The widespread relevance of CMS norm fits in to two major groups. The first version, in fact carries out a statistical decomposition of export performance source into shifts in market share (market penetration effect) and shifts in the market size. Actually this is a simpler version wherein the aggregate data on export is used to measure the norm of constant market share and the factual export performance. The second version of the CMS analysis is slightly more complex and comprehensive which not only consider the market size effect and the competitiveness effect but also it takes into account the commodity composition effect. In this CMS analysis version the competitiveness analysis is in fact a left over term or in other words a residual term. Tyszynski, 1951 was the first one who employed this version of CMS analysis effectively to decompose the export performance (growth) into market size, market composition and competitiveness. Thereafter this method was adopted by many researchers for explaining the export performance. A vital exposition of this method of analysis, specifically on the competitiveness term was provided by Richardson (1971). More critical expositions and theoretical arguments were put forth by Merkies and van der Meer (1988). Moreover, It has also been employed by a many authors to analyze the export performance of developing nations in terms of general competitiveness (Chen, Xu, \& Duan, 2000; Juswanto \& Mulyanti, 2003; Nalin Kumar \& Muraleedharan, 2007; Thi Anh-Dao Tran et al., 2009; Gatto et al., 2011; Beltramello et al., 2012).

Although CMS analysis is widely in use to delineate the critical factors behind the export performance, the approach bears certain grave limitations which should be wisely taken care of especially while inferring the results of the analysis. Chiefly the method is very much susceptible to the extreme points (beginning point and end point) and in the case of presence of any extreme values, it is certain that the analyst would obtain unwelcome results which might eventually lead to erroneous interpretations. To overcome this issue, it is always better to have long periods for the analysis and it is preferred to use the averages of two or three years in the beginning period and in the end period so that even if an extreme value is present, its effect will be smoothened to avoid unstable results. As we have discussed earlier, the competitiveness element in the export growth is a residual term and therefore in addition to competitiveness as such the term might perhaps include factors which can not be straightly attributed to competitiveness. For instance, the policy level changes in trade agreements between trading nations might be reflected in the residual term which may eventually overstate the competitiveness. In essence, it is hard to delineate the impact of competitiveness as such from the other possibly coexisting factors affecting the export growth performance. Having said this, the analysis bears adequate importance since it brings out critical indications regarding market size, market share and maintenance of overall share because of possible policy decisions in the exporting and importing nations. However, the following analysis will certainly enlighten some facets of India's seafood export performance in the world market during the stringent food safety regime.

\section{Methodology}

The analysis was carried out by considering 35 export markets in the case of shrimp and 27 export markets in the case of cephalopods. The list of the export markets/countries are provided in Appendix-1. It should be borne in mind that CMS approach is purely a procedure for disintegrating the growth in exports, and should not be seen in the purview of cause-effect association. This model disintegrates the causes of export dynamics and differentiates between shifts in market access (market share) and shifts in the size of these markets. In Equation- $1,\left(g^{1}-g^{\circ}\right)$ stands for export growth in destination markets (individual countries). The growth component has been disintegrated 
into three market force components. Since in this approach individual countries are given paramount emphasis, the component of country composition effect was not incorporated.

The export decomposition model can be represented as:

$$
g^{l}-g^{0}=R^{0}\left(E^{l}-E^{0}\right)+\sum_{i}\left(R_{i}^{0}-R^{0}\right) * E_{i}{ }^{l}+\left(g^{l}-\sum^{i} R_{i}^{0} E_{i}^{l}\right)
$$

Where,

$g=$ Export of seafood from India to chief destinations (in quantity)

$R=$ Export share of India in the overall quantum of export in the chief markets

$R_{i}=$ The share of Indian exports in total imports of major individual countries

$E=$ Overall quantum of seafood exports in major destination markets/countries

$E_{i}=$ Individual importing country wise total quantum of imports

Note: Here 0 denotes base period and 1 denotes recent period ( 0 and 1 are used as superscripts)

The component $\left(E^{I}-E^{0}\right)$ represents the size of the market effect which implies change in quantity of total exports to $i$ over the period. If this augment / decreases, then even with a constant market share $\left(R^{\circ}\right)$, the exports will augment / decreases by $R^{0}\left(E^{l}-E^{0}\right)$. It is noteworthy that the overall change in demand of individual markets $\left(\Sigma_{i}\right)$ causes the market size effect. On the other hand market composition effect implies the shift/change in the export share of India in the major importing individual countries in comparison with the overall share of Indian seafood export for the importing markets as whole, and for this computation we are considering only the base period. Competitiveness effect $\left(g^{l}-\sum^{i} R_{i}^{0} E_{i}^{l}\right)$ can be termed as a left over component in the analysis. It measures the wedge between the actual quantum of export took place from India to the chief market destinations during the recent period under consideration and the hypothetical quantum of export which could have been realized had India maintained the same market share (of the initial/base period) in each individual countries.

The competitiveness effect reflects the capability of an individual country to access international export markets and elevate the share of export despite the unfavorable shifts in international demand. It is often inferred as a sign of the dynamic capability of a country to counter the altering environment and adjust its supply conditions to international market situations. In nut shell, CMS analysis disintegrates the overall growth in individual exporting country into effect of market composition and effect of market size and the in turn separates the competitiveness effect $\left(g^{l}-\Sigma^{i} R_{i}^{0} E_{i}{ }^{l}\right)$ as a residual component of the analysis.

The fundamental hypothesis of the CMS analysis is that, export shares in the initial/base period are sustained all through the period under consideration. Apparently the market components are computed/delineated based on this fundamental assumption. Theoretically eventhough one is using the data on imports provided by the importing country (Cost Insurance Freight data) or the data on exports provided by the exporting country (Free On Board data), it really does not make any significant difference. But in reality, there are frequent discrepancies between import and export data due to varied grounds. Since CIF data is more comprehensive in terms of coverage of transaction costs we have used the same for the purpose of analysis. The data used for the analysis was sourced from UNCOMTRADE online database and statistical bulletin (various years) of Marine Products Export Development Authority (MPEDA), India.

\section{Results and Discussions}

The CMS framework was used to analyze the export performance of shrimps and cephalopods from India to the dominant seafood importing nations of the world. Here we have purposefully selected a 12 year long period starting from 1996 and ending at 2007. This period was selected keeping view of getting adequate reflections on possible restructuring took place in the seafood processing and export industry of India. To avoid any influence of the single extreme values at both the beginning and end of the selected period we have smoothen the two ends of the study period by using averaging technique. The results of the analysis conducted are presented in the Table 2 . 
Table 2. Decomposition of fishery exports

\begin{tabular}{lll}
\hline Component & Shrimp & Cephalopods \\
\hline Size of the market effect & 92.62 & 20.08 \\
Market composition effect & -33.06 & 25.34 \\
Competitiveness effect & 40.43 & 54.56 \\
\hline
\end{tabular}

While looking at the disintegrated factors determining the export growth of shrimp to the world market, it is quite evident that the effect of competitiveness is less. Moreover the effect of market composition shows a negative index which reflects a decline in export market share in comparison with the other competing countries. Apparently a very high index of the market size effect implies that the growth in export was chiefly contributed by the enhanced import demand in the destination countries. On the contrary to this, in the case of export of cephalopods, among the three components, competitiveness index stands at a much higher level and indubitably explains the growth in export of cephalopods during the period of study. It is evident from the analysis that during the food safety regime competitiveness of export of shrimp, which is an important fishery export item of India in terms of export value, has declined and the competitiveness of export of cephalopods, which is another high value seafood export item from India, has moved up. Now, we know that competitiveness effect is a leftover term in this analysis and as such it would be erroneous, if we attempt to attribute competitiveness as the sole factor causing increase or decrease in export growth. Since it is a residual term, many other factors which were not captured in the disintegration of export components would also get associated with the competitiveness term. Nevertheless, here we are certain to bring out the appropriate signaling for possible interventions at academic and policy levels. We observed that in the context of evolving food safety regime the seafood export dynamics was dissimilar at disintegrated commodity levels. We could have contrasted this with the results of fish and fishery products as a whole (aggregated), but unfortunately we had to restrain since we could not garner a balanced data on quantity of fishery export at aggregate level for the period of study. But nevertheless, the divergent results we obtained for almost similar commodities of export implies the need of high level disaggregated commodity level approaches while examining the impact of food safety regulations on exports.

\section{Conclusions}

The broad objective of the study was to understand the export dynamics of Indian seafood products at disintegrated commodity level in the context of evolving stricter food safety standards and regulations of the major export destinations. The purpose was to get an overall depiction and useful indication/signals in terms of export competitiveness. We have disintegrated the overall export growth of shrimps and cephalopods during the period considered for analysis and found that although both the commodities comes under the same category of fish and fishery products, the export performances differed. The findings suggests that while we attempt to study the impact of trade dynamics (food safety standards are one of its kind) one should go for disintegrated commodity levels to bring out more meaningful results. The results of the present study can be used as modest indicators for further in depth sector wise analysis.

\section{Rferences}

Anders, S. M., \& Caswell, A. J. (2009). Standards as barriers versus standards as catalysts: Assessing the impact of the HACCP implementation on U.S. seafood imports. American Journal of Agricultural Economics, 91(2), 310-321. http://dx.doi.org/10.1111/j.1467-8276.2008.01239.x

Batista, \& Jorge Chami. (2008). Competition between Brazil and other exporting countries in the US import market: a new extension of constant-market-shares analysis. Applied Economics, 40(19), 2477-2487. http://dx.doi.org/10.1080/00036840600970203

Beltramello, A., De Backer, K., \& Moussiegt, L. (2012). The export performance of countries within global value chains (GVCs) (Working Papers, No. 2012/02). Retrieved from OECD Science, Technology and Industry website. http://dx.doi.org 10.1787/5k9bh3gv6647-en

Chen, K., Xu, L., \& Duan, Y. (2000). Ex-post competitiveness of China's export in agrifood products: 1980-1996, Agribusiness, 16(3), 281-294. http://dx.doi.org/10.1002/1520-6297(200022)16:3<281::AID-AGR2>3.0.CO;2-4

Del Gatto, M., di Mauro, F., Gruber, J., \& Mandel, B. (2011). The revealed competitiveness of U.S. exports (International Finance Discussion Paper No 1026). Retrieved from Board of Governors of the Federal 
Reserve System website. Retrieved from http://www.federalreserve.gov/pubs/ifdp/2011/1026/ifdp1026.pdf

Henson, S. (2007). The Role of public and private standards in regulating international food markets. Journal of International Agricultural Trade and Development, 4(1), 52-66

Henson, S., \& Jaffee, Steven, (2008). Understanding developing country strategic responses to the enhancement of food safety standards. The World Economy, 31(4), 548-568. http://dx.doi.org/10.1111/j.1467-9701.2007.01034.x

Juswanto, W., \& Mulyanti, P. (2003). Indonesia's manufactured exports: A constant market share analysis, Jurnal Keuangan dan Moneter, 6(2), 97-106.

Merkies, A., \& Van der Meer, T. (1988). A theoretical foundation for constant market share analysis. Empirical Economics, 13(2), 65-80. http://dx.doi.org/10.1007/BF01973315

MPEDA (2012). Export performance: Marketwise. Retrieved from http://www.mpeda.com

Nalin Kumar, C., \& Muraleedharan, V. R. (2007). SPS regulations and competitiveness: An analysis of Indian spice exports. South Asia Economic Journal, 8(2), 335-346. http://dx.doi.org/10.1177/139156140700800208

Richardson, D. J. (1971). Constant market shares analysis for export growth. Journal of International Economics, 1(2), 227-239. http://dx.doi.org/10.1016/0022-1996(71)90058-4

Tyszynski, H. (1951), World trade in manufactured commodities 1899-1950. The Manchester School of Economic and Social Studies, 19, 222-304. http://dx.doi.org/10.1111/j.1467-9957.1951.tb00012.x

Thi Anh-Dao Tran., Tri Thanh Vo., Hien Minh Dinh., Anh Duong Nguyen., Thien Hoang Pham., \& Quang Long Trinch. (2009). Vietnam's export to EU: An overview and assessment using the constant market share based approach. In Gabriele Tondi. (Ed.), The EU and Emerging markets (pp. 235-263). New York: Spring Wien. 


\section{Appendix 1}

Export markets/Countries selected for CMS analysis

\begin{tabular}{|c|c|c|}
\hline \multirow[t]{2}{*}{ Sl No } & Shrimp & Cephalopods \\
\hline & $\mathrm{N}=35$ & $\mathrm{~N}=27$ \\
\hline 1 & Australia & Australia \\
\hline 2 & Austria & Austria \\
\hline 3 & Bahrain & Belgium \\
\hline 4 & Bangladesh & Canada \\
\hline 5 & Belgium & China \\
\hline 6 & Canada & France \\
\hline 7 & China & Germany \\
\hline 8 & Denmark & Greece \\
\hline 9 & France & Hong \\
\hline 10 & Germany & Italy \\
\hline 11 & Greece & Japan \\
\hline 12 & Hong & Lebanon \\
\hline 13 & Indonesia & Malaysia \\
\hline 14 & Italy & Maldives \\
\hline 15 & Japan & Mauritius \\
\hline 16 & Lebanon & Netherlands \\
\hline 17 & Malaysia & New Zealand \\
\hline 18 & Maldives & Portugal \\
\hline 19 & Mauritius & Rep. of Korea \\
\hline 20 & Mexico & Singapore \\
\hline 21 & Netherlands & South Africa \\
\hline 22 & New Zealand & Spain \\
\hline 23 & Portugal & Sri Lanka \\
\hline 24 & Rep. of Korea & Switzerland \\
\hline 25 & Saudi Arabia & Thailand \\
\hline 26 & Singapore & UK \\
\hline 27 & South Africa & USA \\
\hline 28 & Spain & \\
\hline 29 & Sri Lanka & \\
\hline 30 & Switzerland & \\
\hline 31 & Thailand & \\
\hline 32 & UAE & \\
\hline 33 & UK & \\
\hline 34 & USA & \\
\hline 35 & Viet Nam & \\
\hline
\end{tabular}

